\title{
TECHNOLOGY OF COMPLEX SORPTION TREATMENT OF INDUSTRIAL WASTEWATER FROM SULPHIDE AND COPPER(II)-IONES
}

\author{
O. Khudoyarova ${ }^{1}$, A. Ranskiy ${ }^{2}$, O. Gordienko ${ }^{2}$ \\ ${ }^{1}$ Vinnytsia Mykhailo Kotsiubynskyi State Pedagogical University, 21100, Ukraine, Vinnytsia, \\ Ostrozhskogo street 32, e-mail: helgakhudoyarova@gmail.com \\ ${ }^{2}$ Vinnytsia National Technical University, 21021, Ukraine, Vinnytsia, Khmelnytske road 95
}

DOI: https://doi.org/10.20535/2218-930022021237814

\begin{abstract}
Complex processing of industrial waste of individual industries, including wastewater treatment, containing sulfur anions and cations of heavy metals, in order to obtain both purified water and finished industrial products is an urgent task for today. The possibility of efficient use of regenerated mixed sorbent $(A C+K)$, containing activated carbon $(A C)$ and diatomaceous earth $(K)$, for wastewater treatment of certain technological processes of chemical (petrochemical) industry and galvanic industries has been shown. The sorbent with the removed contaminants was offered to be utilized as a part of plastic lubricants of special purpose. The technological process of complex sorption treatment of industrial wastewater from sulfide and copper (II) ions includes the following main stages: sorbent regeneration; purification of sulfide-alkaline solutions; purification of washing waters of galvanic productions; obtaining plastic oils. The basic technological scheme of the site of regeneration of the spent mixed sorbent $(A C+K)$ and purification of water-sugar solutions from organic impurities was developed. The material balance of regeneration of the spent mixed sorbent was calculated. The basic technological scheme of the site of combined treatment of industrial wastewater from sulfide and copper (II) ions, regeneration of spent industrial oils with regenerated sorbent $(A C+K)$ and production of plastic oils has been developed. It was shown that the technology of complex sorption wastewater treatment is based on the most common technological processes - heating, cooling, adsorption and filtration and does not require complex schemes of automatic process control, and chemical equipment is typical for chemical enterprises in Ukraine. The economic effect of production of special purpose plastic oils was calculated.
\end{abstract}

Keywords: basic technological scheme, industrial wastewater, technology of complex treatment, sorption methods, utilization

Received: 28 July 2021

Revised: 5 September 2021

Accepted: 28 September 2021

\section{Introduction}

The industrial wastewater of many chemical plants contains a significant amount of substances which are harmful to natural water bodies and human health, which contain sulfur anions and cations of a number of heavy metals. Therefore, toxic solutions containing such cations and anions are sometimes diluted with water to reduce the concentration below the MPC. However, this procedure cannot always be performed, so there is a problem of mandatory water treatment. To implement such water treatment, various physicochemical methods are used, among which the most popular method of adsorption using a variety of both natural and synthetic adsorbents. To increase the sorption capacity, it is popular to modify the sorption matrix using harmless and available reagents. Analysis of recent research 
and publications $[9-12,13]$ has shown that the joint processing and disposal of waste from different industries allows you to remove valuable chemical compounds and significantly improve the ecological condition of the environment in their storage. The complex utilization of industrial waste studied today concerns, first of all, reagent extraction of metal cations from sewage of galvanic productions and other chemical wastes by their interaction and formation of waterinsoluble chemical compounds. The latter, as a rule, act as raw materials in their subsequent heat treatment. However, all existing methods of joint processing and utilization of waste from different industries have significant shortcomings, especially in the environmental plan.

Therefore, the aim of the work is to develop the technology of effective complex purification of industrial waters of copper processes from $\mathrm{Cu}^{2+}$ and sulfide-alkaline solutions of chemical and petrochemical productions from $\mathrm{S}^{2-}$ and $\mathrm{HS}^{-}$in order to obtain both purified water and final industrial products.

\section{Materials and methods}

The subject of the study were complex adsorption technologies for wastewater treatment of individual industries, namely:

- sulfide-alkaline solutions, which in terms of concentrations of sulfide and hydrosulfide ions are close to the wastewater of the intermediate pond, which was located on the territory of the industrial zone of Kremenchug refinery (PJSC "Ukrtatnafta");

- wash water of the process of electrochemical copper plating, which was carried out using acid electrolytes;

- water-sugar solutions, which were subject to purification after regeneration of a mixed sorbent $(\mathrm{AC}+\mathrm{K})$, consisting of activated carbon (AC) brand Decolar A and kieselguhr (K) brands Bekogur 200 and Bekogur 3500 in a mass ratio of 4: 6 .

In addition, spent industrial oils I-40A and Arian MGE-46 B were subject to adsorption purification. Regenerated industrial oils were subsequently used as a component of special purpose plastic oils.

All studies are united by the fact that they were performed by using a single sorbent - regenerated mixed sorbent $(\mathrm{AC}+\mathrm{K})$.

Regeneration of the spent mixed sorbent $(\mathrm{AC}+\mathrm{K})$ after the stage of purification of sugar syrup production of soft drinks was carried out according to the method described in works $[6,7]$. Methods of purification of water-sugar solutions are described in work [7], sulfide-alkaline solutions - in work [8-11], washing waters of the electrochemical copper plating process - in work [12]. Regeneration of waste industrial oils was carried out according to the method presented in work [13]. Plastic lubricants, which contained regenerated oils and spent sorbent after wastewater treatment from $\mathrm{S}^{2-}$ and $\mathrm{Cu}^{2+}$ ions, were prepared according to the method [10].

\section{Results and discussion}

An integrated approach to the adsorption method of wastewater treatment of individual industries and disposal of waste sorbents includes:

- regeneration of spent mixed sorbent $(\mathrm{AC}+\mathrm{K})_{\mathrm{S}}$ after the stage of purification of sugar syrup for the production of soft drinks and purification of water-sugar solutions after regeneration of the sorbent using regenerated sorbent $(\mathrm{AC}+\mathrm{K})$;

- purification of sulfide-alkaline solutions of chemical (petrochemical) 
productions from $\mathrm{S}^{2-}$, $\mathrm{HS}^{-}$- ions with the use of regenerated sorbent $(\mathrm{AC}+\mathrm{K})$;

- purification of washing waters of galvanic productions from $\mathrm{Cu}^{2+}$ ions with the use of the modified sulfide ions of sorbent $\left(\mathrm{AC}+\mathrm{K}+\mathrm{Na}_{2} \mathrm{~S}\right)$;

- regeneration of waste industrial oils using regenerated sorbent $(\mathrm{AC}+\mathrm{K})$;

- production of new carbon-sulfurcontaining plastics using regenerated oils and spent sorbent $(\mathrm{AC}+\mathrm{K}+\mathrm{CuS}+\mathrm{S})$.

The developed technological scheme of complex sorption treatment of industrial wastewater from sulfide and copper (II) ions consists of:

- areas of regeneration of the mixed sorbent $(\mathrm{AC}+\mathrm{K})$ and purification of watersugar solutions after regeneration of the sorbent;

- areas of combined treatment of industrial wastewater from $\mathrm{Cu}^{2+}, \mathrm{S}^{2-}, \mathrm{HS}^{-}$ions, regeneration of spent industrial oils with regenerated sorbent $(\mathrm{AC}+\mathrm{K})$ and production of plastic lubricants.

\subsection{Sorbent regeneration technology} and its use for industrial water purification

Based on the results of research obtained in works [6, 7], we have developed a basic technological scheme of the regeneration of the spent mixed sorbent $(\mathrm{AC}+\mathrm{K})$ and purification of water-sugar solutions after regeneration of the sorbent, which is shown in Fig. 1. The operation of the first chain of collector-mixers concerns the regeneration of the spent sorbent $(\mathrm{AC}+\mathrm{K})_{\mathrm{S}}$ after the stage of purification of the sugar syrup solution in the following sequence: $\mathrm{R}$ $1 \rightarrow \mathrm{R}-2 \rightarrow \mathrm{R}-3 \rightarrow \mathrm{R}-4$. In each of these collectors-displacers $\mathrm{R}-1 \div \mathrm{R}-4$ using the source capacities $\mathrm{C}-1 \div \mathrm{C}-4$ and the corresponding dispensers D-1 $\div$ D-4 loaded the calculated amount of spent source sorbent $(\mathrm{AC}+\mathrm{K})_{\mathrm{S}}$ (collector- mixer R-1) and partially regenerated mixture of sorbents $(\mathrm{AC}+\mathrm{K}) \mathrm{I} \div$ $(\mathrm{AC}+\mathrm{K}) \mathrm{III}:(\mathrm{AC}+\mathrm{K}) \mathrm{I} \rightarrow$ in $\mathrm{R}-2$; $(\mathrm{AC}+\mathrm{K}) \mathrm{II} \rightarrow$ in $\mathrm{R}-3$; $(\mathrm{AC}+\mathrm{K}) \mathrm{III} \rightarrow$ in $\mathrm{R}-4$. In the first collector-mixer R-1 was added water for primary washing of the spent sorbent $(\mathrm{AC}+\mathrm{K})_{\mathrm{S}}$ from water-soluble organic compounds (sugar, glucose, etc.); in the second $\mathrm{R}-2-1 \% \mathrm{NaOH}$ solution; in the third $\mathrm{R}-3$ - 4\% $\mathrm{HCl}$ solution; in the fourth $\mathrm{R}-4$ (control) - water for final purification of the regenerated sorbent $(\mathrm{AC}+\mathrm{K}) \mathrm{IV}$ from mineral salts. Sequential movement of each subsequent cleaner fraction of sorbents $(\mathrm{AC}+\mathrm{K})$ was performed using pumps $\mathrm{P}-1 \div \mathrm{P}$ 4 and the corresponding filters $\mathrm{F}-\mathrm{I} \div \mathrm{F}-4$. The use of three-stage technology of regeneration of spent sorbents allows to $100 \%$ restore the sorption capacity of the regenerated mixture $(A C+K) I V$. It should be noted that the alkaline filtrate from the collector-mixer R-2 is neutralized by acid filtrate from the collector $\mathrm{R}-3$ to $\mathrm{pH}=7$ and fed into the technical water system of the enterprise.

The operation of the second chain of collectors-mixers of industrial water purification from organic impurities could be presented in the following sequence: $\mathrm{R}-5 \rightarrow \mathrm{R}-6 \rightarrow \mathrm{R}-7$. In this case, from the storage tank of contaminated water to be purified C-5, through the dispenser D-5 in the collectormixer R-5 contaminated water is supplied, which is subject to three-stage sorption purification in successive passage of the collector-mixers, which was mentioned earlier. The working sorbent is regenerated, according to the previously mentioned first chain of technological transformations, sorbent $(\mathrm{AC}+\mathrm{K}) \mathrm{IV}$. Sequential movement of each subsequent cleaner volume of technical water $\mathrm{F}-1 \rightarrow \mathrm{F}-2 \rightarrow \mathrm{F}-3$ was performed using 
pumps $\mathrm{P}-5 \div \mathrm{P}-7$ and the corresponding filters F-5 $\div$ F-7. The use of this three-stage technology of industrial water purification for one technological cycle allowed to reduce 2.9 times the amount of sugar in the water to be purified. It should be noted that the technological operations of the first and second chains are interrelated. Thus, the sorbent $(\mathrm{AC}+\mathrm{K})$, which does not meet the technical requirements, is moved from the second technological chain to the first for its subsequent regeneration.

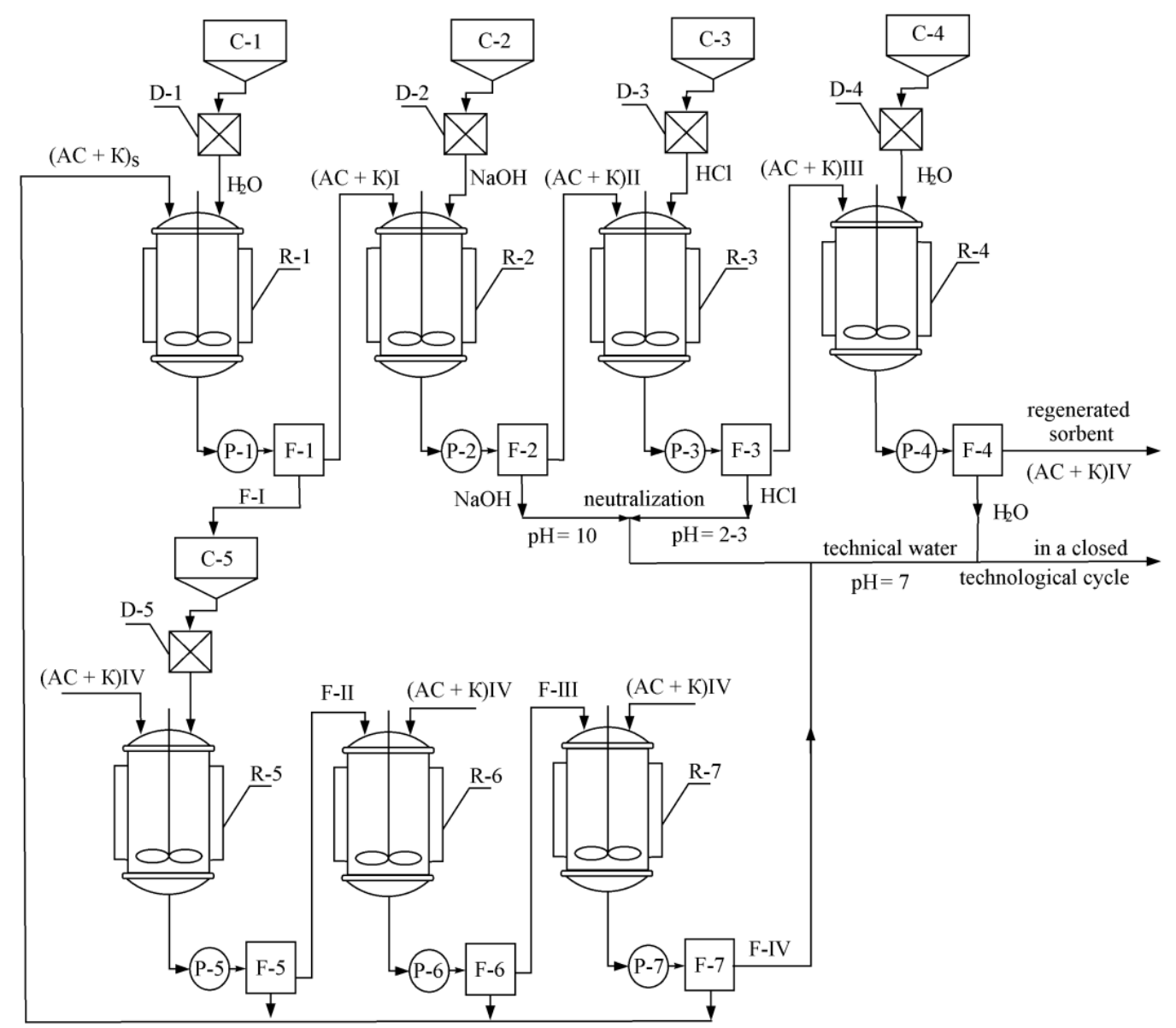

Fig. 1. Basic technological scheme of the area of regeneration of the spent mixed sorbent $(A C+K)$ and purification of industrial water from organic impurities: $R-1 \ldots R-7$ - collectors-mixers; P-1... P-7 - pumps; F-1... F-7 - filters; D-1.. D-5 - dispensers; $C-1 \ldots C-5$ - capacities; $(A C+K)_{S}$ - spent mixed sorbent; $(A C+K) I \ldots(A C+K) I I I-$ mixed sorbent after I... III degree of purification; $(A C+K) I V$ - regenerated mixed sorbent; $F-I$ - solution after washing with water of the spent mixed sorbent; F-II, F-III - solutions after collectors-mixers $R-5$, R-6; F-IV - purified water

In order to determine the material costs for the regeneration of spent sorbent, we calculated the material balance of regeneration of $100 \mathrm{~kg}$ of spent mixed sorbent $(\mathrm{AC}+\mathrm{K})$ (Table 1). From the Table 1 data of the material balance of regeneration of the spent mixed sorbent, the following conclusions can be drawn:

- the proposed technology of regeneration of spent sorbent $(\mathrm{AC}+\mathrm{K})$ allows to restore $100 \%$ of its sorption capacity with a yield of $98 \%$; 
- a significant amount of technical water $995 \mathrm{dm}^{3}(\sim 83 \%)$, which is used, is supplied for repeated sorption purification with the formation of a closed technological cycle;

- process water contains a small amount of non-toxic organic and inorganic pollutants;
- technology of regeneration of a mixture of sorbents $(\mathrm{AC}+\mathrm{K})$ (Fig. 1) includes typical chemical equipment and the simplest chemical operations dissolution, adsorption, mixing and filtration.

Table 1. Material balance of regeneration of $100 \mathrm{~kg}$ of spent mixed sorbent

\begin{tabular}{|c|c|c|c|c|c|}
\hline \multicolumn{3}{|c|}{ Downloaded } & \multicolumn{3}{|c|}{ Received } \\
\hline Name & $\begin{array}{c}\text { Weight, } \\
\text { kg }\end{array}$ & $\begin{array}{c}\text { The mass } \\
\text { fraction, } \\
\%\end{array}$ & Name & $\begin{array}{c}\text { Weight, } \\
\text { kg }\end{array}$ & $\begin{array}{c}\text { The mass } \\
\text { fraction, } \\
\%\end{array}$ \\
\hline 1. Spent mixed sorbent & 100.0 & 9.09 & $\begin{array}{l}\text { 1. Regenerated mixed } \\
\text { sorbent }\end{array}$ & 98.0 & 8.91 \\
\hline 2. $\mathrm{H}_{2} \mathrm{O}$ & 800.0 & 72.73 & $\begin{array}{c}\text { 2. Water contaminated } \\
\text { with organic and inorganic } \\
\text { substances: }\end{array}$ & 997.0 & 90.64 \\
\hline $\begin{array}{l}\text { 3. } \mathrm{NaOH}, 1 \% \text { of the } \\
\text { mass. solution, of } \\
\text { which }\end{array}$ & 100.0 & 9.09 & $\begin{array}{l}\text { - } \text { sugar and other } \\
\text { organic substances }\end{array}$ & 0.5 & 0.04 \\
\hline$-\mathrm{NaOH}$ & 1.0 & 0.09 & $-\mathrm{NaCl}$ & 1.46 & 0.13 \\
\hline$-\mathrm{H}_{2} \mathrm{O}$ & 99.0 & 9.00 & \multirow{4}{*}{ 3. Losses } & \multirow{4}{*}{5.0} & \multirow{4}{*}{0.45} \\
\hline $\begin{array}{l}\text { 4. } \mathrm{HCl}, 4 \% \text { of the } \\
\text { mass. solution, of } \\
\text { which }\end{array}$ & 100.0 & 9.09 & & & \\
\hline$-\mathrm{HCl}$ & 4.0 & 0.36 & & & \\
\hline$-\mathrm{H}_{2} \mathrm{O}$ & 96.0 & 8.73 & & & \\
\hline Total & 1100.0 & 100.0 & Total & 1100.0 & 100.0 \\
\hline
\end{tabular}

3.2. Complex technology of sorption purification of industrial waters from $\mathrm{Cu}^{2+}$, $S^{2-}, H S^{-}$-ions and technical and economic substantiation of production of plastic lubricants with use of extracted components

Work of the basic technological scheme of the site of industrial water purification from $\mathrm{Cu}^{2+}, \mathrm{S}^{2-}, \mathrm{HS}^{-}$-ions, regeneration of the fulfilled industrial oil
I-40A and the production of plastic oils (Fig. 2) is based on the results of research presented in [1-5, 8].

The operation of the third line of collector-mixers in the sequence $\mathrm{R}-1 \rightarrow \mathrm{R}-2 \rightarrow \mathrm{R}-3$ concerned the sorption purification of sulfide-alkaline solutions from $\mathrm{S}^{2-}, \mathrm{HS}^{-}$-ions, and the operation of the collector-mixer R-4 concerned the production of a modified mixture of sorbents 
$(\mathrm{AC}+\mathrm{K}+\mathrm{CuS}+\mathrm{S})$. In each of these collectorsmixers $\mathrm{R}-1 \div \mathrm{R}-3$ using the tank $\mathrm{C}-2$ for the regenerated sorbent $(\mathrm{AC}+\mathrm{K}) \mathrm{IV}$, as well as the tank $\mathrm{C}-1$ for the original sulfide-alkaline solution and the corresponding dispensers D-1, D-2 downloaded the calculated amount of sorbent. The reaction mixture was stirred by using the pumps $\mathrm{P}-1 \div \mathrm{P}-3$ and the corresponding filters $\mathrm{F}-1 \div \mathrm{F}-3$ fed a modified mixture $\left(\mathrm{AC}+\mathrm{K}+\mathrm{Na}_{2} \mathrm{~S}\right)$ through the tank $\mathrm{C}-4$ and the dispenser D-3 in the collector-mixer R-4. By adding from the tank C-5 through the dispenser D-4 galvanic copper washing water and the calculated amount of modified sorbent $\left(\mathrm{AC}+\mathrm{K}+\mathrm{Na}_{2} \mathrm{~S}\right)$, stirring the reaction mass in the collector-mixer R-4 was obtained a modified mixture of sorbents $(\mathrm{AC}+\mathrm{K}$ $\mathrm{CuS}+\mathrm{S})$. The degree of extraction of total sulfur $\left(S_{\mathrm{g}}\right)$ from sulfide-alkaline solutions is $97 \%$, and $\mathrm{Cu}^{2+}$ ions from wash water $-83 \%$.

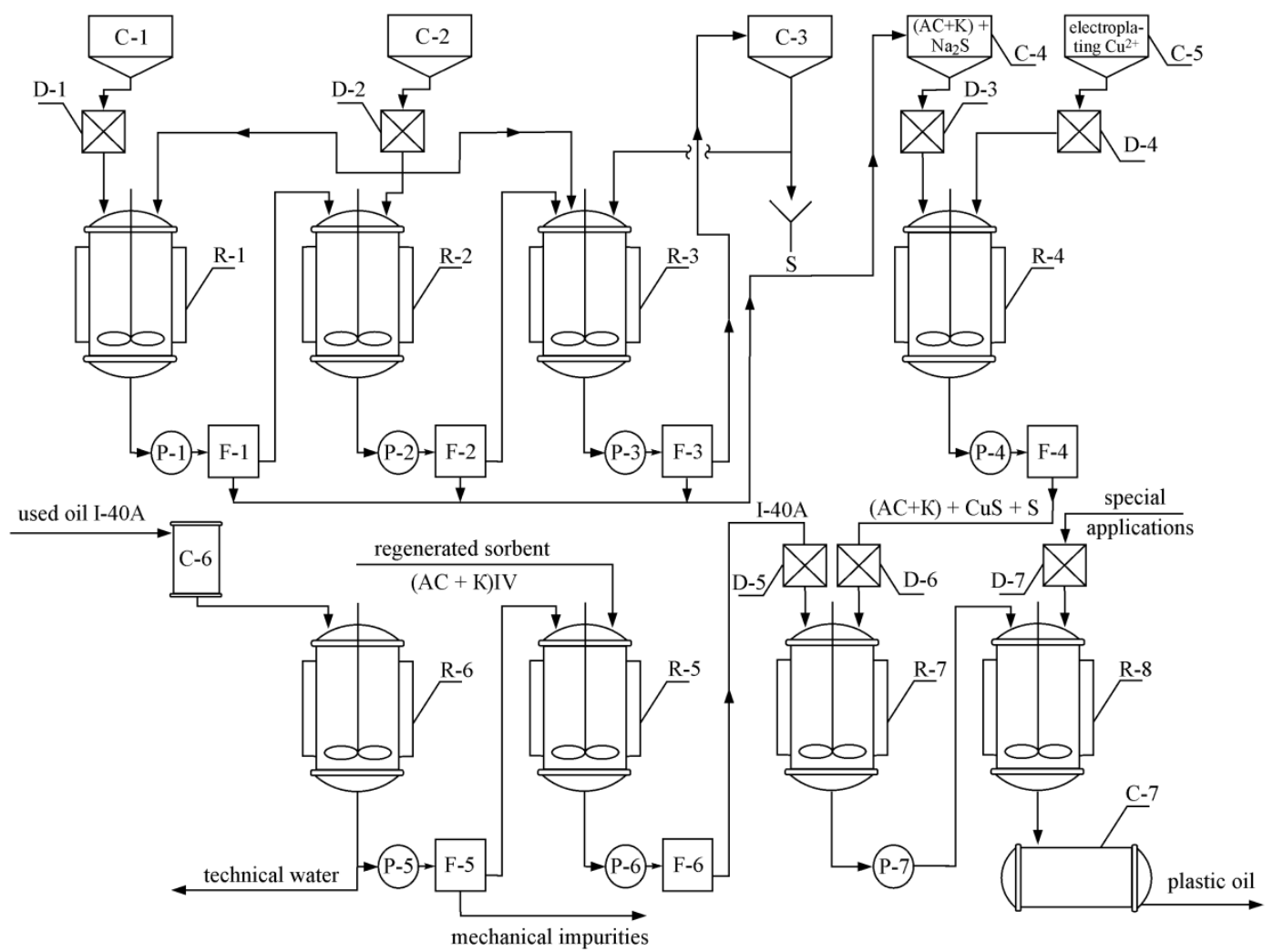

Fig. 2. Complex technological scheme of industrial water purification area from $\mathrm{Cu}^{2+}, \mathrm{S}^{2-}$, $H S^{-}$-ions, regeneration of spent industrial oils and production of plastic oils: $R-1 \ldots R-5$ - collectorsmixers; $R-7, R-8$ - dispersants for plastic lubricants; $C-1 \ldots C-6$ - containers for working solutions and starting compounds; C-7 - capacity for finished products of PM;D-1.. D-7 - dispensers for liquid and bulk products; P-1... P-7 - pumps; F-1... F-6 - filters; $S$ - sewage system (sewerage)

The work of the fourth line of collectorsmixers R-6, R-5 concerned the sorption regeneration of industrial oil $\mathrm{I}-40 \mathrm{~A}$ and obtaining in dispersants-mixers R-7, R-8 plastic oil of the PM series. To do this, the spent oil I-40 A from the tank C-6 was fed into the disperser-mixer R-6, mixed, if necessary, heated to $50-60{ }^{\circ} \mathrm{C}$, defended and separated from water and mechanical impurities. In the collector-mixer R-5 fed purified from water and mechanical impurities oil I-40A, as well as the calculated amount of sorbent $(\mathrm{AC}+\mathrm{K}) \mathrm{IV}$ from the first line of purification (regeneration) of the spent 
mixture of sorbents $(\mathrm{AC}+\mathrm{K})_{\mathrm{S}}$ (Fig. 1). Purified from oxidation products and clarified industrial oil I-40A through the dispenser D-5 and a modified mixture of sorbents $(\mathrm{AC}+\mathrm{K}+\mathrm{CuS}+\mathrm{S})$ through the dispenser D-6 was provided into the disperser-mixer R-7. The homogenized mixture of composite lubricants from the disperser R-7 was pumped P-7 into the disperser-mixer R-8, through the dispenser D-7 added other special additives of plastic lubricants series PM and carried out the final homogenization to form a stable plastic mass. Ready-to-use plastic oils were collected in the C-7 tank.

Feasibility study for the production of plastic oils of the PM series was carried out by comparing the cost of 1 ton of plastic oils of the PM series with the cost of commercial oil Konstantin-1 (GOST 1957-73) as of 01.09.2019. It was calculated that the economic effect in the production of 1 ton of plastic oil series PM is $41584 \mathrm{UAH}$.

\section{Conclusions}

1. The basic technological scheme of the area of regeneration of the spent mixed sorbent $(\mathrm{AC}+\mathrm{K})$ with restoration of sorption capacity $(\mathrm{AC}+\mathrm{K})$ to $96,7-100 \%$ and purification of industrial water of production of soft drinks from organic impurity which can be successfully used in practice for regeneration mixed sorbent $(\mathrm{AC}+\mathrm{K})$ and reuse of purified water in closed technological cycles has been developed. It was shown that in one cycle the sugar content, as the main pollutant of industrial water, decreases by 2.9 times, which indicates the effectiveness of the developed technology.

2. The basic technological scheme of the site of industrial water purification from $\mathrm{Cu}^{2+}, \mathrm{S}^{2-}, \mathrm{HS}^{-}$-ions, regeneration of spent industrial oils and production of plastic oils is developed, which can be successfully used in practice both for purification of industrial water from toxic pollutants and for production competitive technical products in the form of special purpose lubricants. The degree of extraction of total sulfur $(\mathrm{Sg})$ from solutions is $97 \%$, and $\mathrm{Cu}^{2+}$ ions $-83 \%$.

3. Feasibility study of expediency of production of plastic lubricants for special purposes with the use of modified mixed sorbent $(\mathrm{AC}+\mathrm{K}+\mathrm{CuS}+\mathrm{S})$ is carried out. It was calculated that the economic effect in the production of 1 ton of plastic oil series PM is 41584 UAH.

\section{Refences}

1. Ranskiy, A. P.; Polonets, O.V.; Panchenko, T.I. etc. Combined processing of highly toxic wastes of industrial production, III AllUkrainian Congress of Ecologists with International Participation: a collection of scientific articles, Vinnytsia, 2011.

2. Ranskiy, A.P.; Plaksienko, I.L.; Shram, V.P.; Shebitchenko, L.N.; Gaididey, O.V. Patent Ukraine 56618, 15.05.2003.

3. Ranskiy, A.P.; Panasyuk, O.G.; Tkachuk, M.F.; Pobirchenko, O.V.; Boyko, S.R.; Shebitchenko, L.N.; Gerina, L.S. Patent Ukraine 34806, 15.03.2001.

4. Ranskiy, A.P.; Petruk, R.V.; Stepanov, D.V.; Evseeva, D.V.; Gordienko, O.A.; Polonets, O.A. Patent Ukraine 65804, 12.12.2011.

5. Zamatirina, V.A. Method of wastewater treatment from heavy metals and petroleum products using modified organobentonite. Diss. Cand. of Science, Saratov, 2015.

6. Ranskiy, A.P; Khudoyarova, O.S.; Gordienko, O.A.; Kryklyvyi, R.D.; Titov, T.S. (VNTU, Ukraine). Method of regeneration of a mixture of activated carbon and diatomaceous earth from organic 
pollutants. Patent Ukraine 134391, 05.10.2019.

7. Ranskiy, A.P.; Khudoyarova, O.S.; Gordienko, O.A. et al. Regeneration of Sorbents Mixture After the Purification of Recycled Waterin Production of Soft Drinks. J. Water Chem.Technol 2019, 5 (271), 318321.https://doi.org/10.3103/S1063455X19050 084.

8. Khudoyarova, O.; Gordienko, O.; Blazhko, A.; Sydoruk, T.; Ranskiy, A. Desulfurization of industrial water-alkaline solutions and receiving new plastic oils. Journal of Ecological Engineering 2020, 21 (6), 61-66.

https://doi.org/10.12911/22998993/123254.

9. Khudoyarova, O.S; Gordienko, O.A; Titov, T.S, Ranskiy, A.P; Kryklyvyi, R.D. Desulfurization of industrial sulfide-alkaline solutions with mixed sorbents. Visnyk VPI 2020, 1 (148), 13-22.

https://doi.org/10.31649/1997-9266-2020148-1-13-22.

10. Khudoyarova, O.; Gordienko, O.; Sydoruk, T.; Titov, T.; Petruk, R.; Prokopchuk, S. Adsorptive desulfurization of sewage of industrial production. Environmental problems 2020, 2(5), 102-106. doi.org/10.23939/ep2020.02.102.
11. Ranskiy A.P, Khudoyarova O.S, Gordienko O.A, Titov T.S, Tserklevych D.R, Kornienko B.V. (VNTU, Ukraine). Method of purification of industrial wastewater from sulfide and hydrosulfide ions. Patent Ukraine 139177, 12/26/2019.

12. Khudoyarova, O.S; Gordienko, O.A.; Sydoruk, T.I.; Titov, T.S.; Ranskiy, A.P. Modification of the surface of mixed sorbents with sulfide ions for purification of galvanic wash water of the copper plating process. Bulletin of the National Technical University of Ukraine "Kyiv Polytechnic Institute named after Igor Sikorsky". Chemical engineering, ecology and resource conservation 2020, 2 (19). 36-46. https://doi.org/10.20535/26179741.2.2020.208054.

13. Khudoyarova, O; Gordienko, O.; Titov, T.; Ranskiy, A.; Dykha, A. Adsorptive regeneration of waste industrial oils, Problems of tribology 2020, 2 (96), 1924. https://doi.org/10.31891/2079-1372-202096-2-19-24. 


\title{
ТЕХНОЛОГІЯ КОМПЛЕКСНОГО СОРБЦЙНОГО
}

\section{ОЧИЩЕННЯ ПРОМИСЛОВИХ СТІЧНИХ ВОД ВІД СУЛЬФІД- ТА КУПРУМ(II)-IOHIB}

\author{
О.С. Худоярова ${ }^{1}$, А.П. Ранський², О.А. Гордієнко \\ ${ }^{1}$ Вінницький державний педагогічний університет імені Михайла Коцюбинського \\ ${ }^{2}$ Вінницький національний технічний університет
}

\begin{abstract}
Комплексне перероблення промислових відходів окремих виробництв, зокрема і очищення стічних вод, що містять аніони сульфуру та катіони важких металів, з метою отримання як очищеної води, так $i$ кінцевої промислової продукції є актуальним завданням сьогодення. Показано можливість ефективного використання регенерованого сумімевого сорбенту $(A B+K)$, що містить активоване вугілля $(A B)$ та кізельгур $(K)$, для очищення стічних вод окремих технологічних прочесів хімічної (нафтохімічної) промисловості та гальванічних виробництв. Сорбент з вилученими забруднювачами запропоновано утилізувати у складі пластичних мастил спеціального призначення. Технологічний прочес комплексного сорбційного очищення промислових стічних вод від сульфід- та купрум(II)-іонів включає такі основні стадії: регенерачія сорбенту; очищення сульфідно-лужних розчинів; очищення промивних вод гальванічних виробнищтв; отримання пластичних мастил. Розроблено принципову технологічну схему ділянки регенеращії відпраџьованого сумімевого сорбенту $(A B+K)$ та очищення водно-иукрових розчинів від органічних домішок. Розраховано матеріальний баланс регенерації відпрацьованого сумішевого сорбенту. Розроблено принцииову технологічну схему ділянки комбінованого очищення промислових стічних вод від сульфід- та купрум(II)-іонів, регенерації відпрацьованих індустріальних олив регенерованим сорбентом $(A B+K)$ та отримання пластичних мастил. Показано, щзо технологія комплексного сорбиійного очищення стічних вод трунтується на найбільш поширених технологічних прочесах - нагріванні, охолодженні, адсорбиії та фільтруванні та не потребує складних схем автоматичного управління процесом, а хімічне обладнання є типовим для хімічних підприємств Украӥни. Розраховано економічний ефект виробниитва пластичних мастил спеціального призначення.
\end{abstract}

Ключові слова: промислові стічні води, технологія комплексного очищення, сорбиійні методи, приниииова технологічна схема, утилізаиія 